\section{AB1142 VITAMIN D LEVELS AND ASSOCIATION WITH DISEASE ACTIVITY IN PARAGUAYAN SLE PATIENTS}

L. Román ${ }^{1}$, G. Avila Pedretti ${ }^{1}$, M.E. Acosta ${ }^{2}$, M. Melo ${ }^{1}$, M.T. Martinez ${ }^{1}$, D. Margarita ${ }^{1}$, I. Acosta Colman ${ }^{1} .{ }^{1}$ Facultad de Medicina- UNA; ${ }^{2}$ Producción, Instituto de Investigación en Ciencias de la Salud, Asunción, Paraguay

Background: Systemic Lupus Erythematosus (SLE) is a systemic inflammatory disease associated with genetic, environmental, hormonal and immunological factors. Vitamin D levels are nowadays considered as one possible factor associated with disease activity. Therefore, previous studies have analyzed vitamin $D$ to the severity of SLE.

Objectives: To assess the Vitamin D status in paraguayan SLE patients and its association with disease activity.

Methods: An observational Trial has been performed on individuals diagnosed with SLE. Epidemiological, clinical and biochemical data have been recorded for each patient to study the association between vitamin D concentrations, the phospho-calcium metabolism parameters and disease activity. Quantitative determination of Vitamin D was perform using chemoluminescence ARCHITEC assay. Vitamin D status was interpreted as follows: deficiency $\leq 20 \mathrm{ng} / \mathrm{ml}$ and insufficiency $21-29 \mathrm{ng} / \mathrm{ml}$. The statistical association tests were performed using linear (SLEDAl activity index) and logistic (Inactive/Mild vs Moderate/Severe) regressions. The epidemiological, clinical and biochemical variables were used as explanatory variables in these models. This study is a preliminary analysis of a trial supported by CONACYT (Paraguay) to investigate the role of vitamin D in patients diagnosed with SLE.

Results: We included 77 SLE patients, of whom $94.8 \%(73 / 77)$ were female. The average age of patients at the time of the study was $30.7 \pm 10.3$ years. All patients received calcium supplements associated with vitamin $D$. The average vitamin $D$ concentration was $32.2 \pm 12.10 \mathrm{ng} / \mathrm{ml}$. 29.9\% (23/77) of patients had vitamin D insufficiency and $13.0 \%$ had vitamin D deficiency. $94.8 \%$ (73/77) of the population had normal serum calcium and the total population had a normal phosphoremia. As for the dosage of PTH, it was found that $27.3 \%(21 / 77)$ have high values of PTH. 20.8\% (16/77) of the patients had positive anti-DNA. Low C3 complement was observed in 30/77 (39\%) and low C4 in 50/77 (64.9\%) patients.

The mean value of SLEDAl at the time of the study was $2.32 \pm 2.83$. When we study the distribution of vitamin $\mathrm{D}$ concentration according to the disease activity (SLEDAI) a clear pattern is observed linking lower vitamin D concentrations with higher disease activity (Figure 1). Patients with lower vitamin D concentrations are more likely to have higher disease activity (OR $0.93,95 \% \mathrm{Cl} 0.88-0.99$;PValue $=0.059$. The means and standard deviations of vitamin $\mathrm{D}$ depending on the SLEDAI activity index are provided in Table 1.

Table 1. Mean and standard deviation of each patient group according to the ranges of SLEDAI activity index

\begin{tabular}{lcc}
\hline SLEDAI & Mean & Standard deviation \\
\hline $0-1$ & 32.41 & 9.61 \\
$2-3$ & 34.59 & 13.37 \\
$4-5$ & 32.28 & 14.38 \\
$6-8$ & 25.8 & 7.61 \\
$>8$ & 22.03 & 18.13 \\
\hline
\end{tabular}

Figure 1. Distribution of vitamin D depending on the SLEDAl activity index

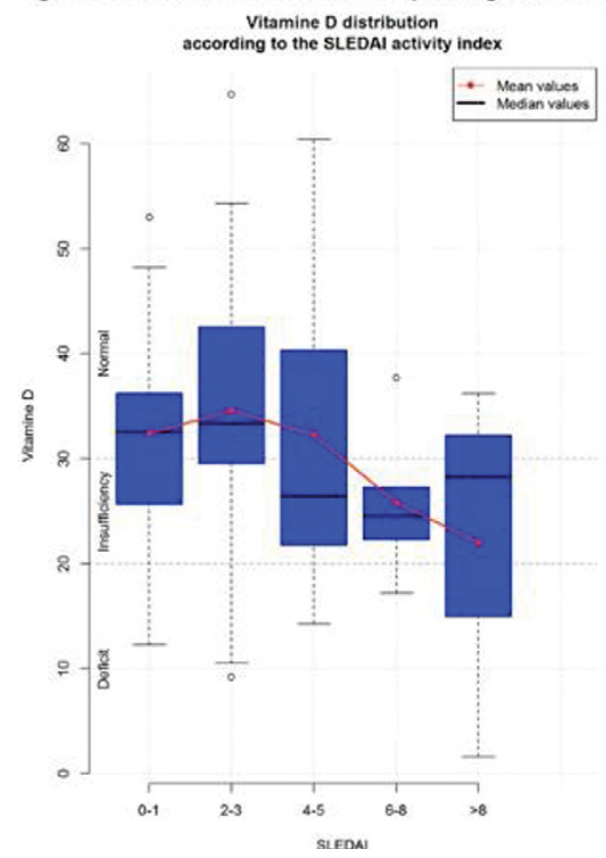

Conclusions: In this preliminary study of Paraguayan SLE patients, Vitamin D deficiency was frequent despite treatment with supplements. In addition, a clear association between SLEDAI and Vitamin D values was observed. The final analysis in a larger patient cohort will have to confirm these findings and clarify relation with disease activity.

References:

[1] Eloi M, Horvath DV, Ortega JC, Prado MS, Andrade LE, Szejnfeld VL, de Moura Castro CH. 25-Hydroxivitamin D Serum Concentration, Not Free and Bioavailable Vitamin D, Is Associated with Disease Activity in Systemic Lupus Erythematosus Patients. PLoS One. 2017 Jan 13;12(1).

Disclosure of Interest: None declared

DOI: 10.1136/annrheumdis-2017-eular.3322

\section{AB1143 THE IMPACT OF ANTI-CYCLIC CITRULLINATED PEPTIDE SEROPOSITIVITY ON EROSION PREVALENCE AMONG PATIENTS WITH RHEUMATOID ARTHRITIS OF VARYING DISEASE DURATION}

L. Harrold ${ }^{1}$, K. Price ${ }^{2}$, H. Litman ${ }^{3}$, S. Connolly ${ }^{2}$, E. Alemao ${ }^{2}$, S. Rebello ${ }^{3}$, W. Hua ${ }^{3}$, J. Kremer ${ }^{4} .{ }^{1}$ University of Massachusett, Worcester: ${ }^{2}$ Bristol-Myers Squibb, Princeton; ${ }^{3}$ Corrona, LLC, Southborough; ${ }^{4}$ Albany Medical College and The Center for Rheumatology, Albany, United States

Background: Little is known regarding the prevalence of erosive disease in a contemporary cohort of patients with RA and whether erosive disease prevalence differs by disease duration and seropositivity to anti-citrullinated protein antibodies (ACPA).

Objectives: To characterize the proportion of patients with RA with erosive disease by disease duration category and stratified by positive and negative serological status (anti-cyclic citrullinated peptide [anti-CCP], a surrogate for ACPA).

Methods: We identified patients with RA aged $\geq 18$ years who were enrolled in the Corrona registry (October 2001-June 2016), with available disease duration, radiographic/MRI/ultrasound studies and serological status based on anti-CCP. Patients were grouped based on RA disease duration $(0-2,3-5,6-10$ and $>10$ years from diagnosis). Unadjusted prevalence erosion rates were calculated based on the proportion of patients with reports of erosions present on joint radiographs/MRIs/ultrasounds. Seropositivity was based on laboratory results (anti-CCP $\geq 20 \mathrm{U} / \mathrm{mL}$ ) at enrolment in the Corrona registry. Chi-squared tests were used to assess differences in prevalence rates.

Results: There were 9759 patients who met inclusion criteria. Most were women $(76 \%)$, middle-aged (mean [SD] 57 years [14]), with moderate disease activity (mean [SD] CDAI 14.7 [13.4]). Prior use of at least one biologic or targeted synthetic DMARD had occurred in $41 \%$ of patients. Overall, the prevalence of erosive disease was $28.6 \%$, with higher prevalence among CCP+ $(35.4 \%)$ vs CCP- $(20.1 \%)$ patients $(p<0.001$, chi-squared test). The prevalence of erosions increased with increasing disease duration $(p<0.001$; Table). For each disease duration group, the prevalence of erosions was higher in patients who were CCP+ compared with those who were CCP-

Table 1. Prevalence of Erosions According to Disease Duration and Serological Status

\begin{tabular}{lcccc}
\hline & \multicolumn{4}{c}{ Disease duration (years) } \\
\cline { 2 - 5 } & $0-2$ & $3-5$ & $6-10$ & $>10$ \\
\hline Overall & $19.3(905 / 4699)$ & $28.3(475 / 1678)$ & $33.4(469 / 1404)$ & $47.8(946 / 1978)$ \\
Serological status & & & \\
$\quad$ CCP- & $16.1(359 / 2226)$ & $22.7(169 / 744)$ & $21.8(128 / 588)$ & $28.1(206 / 733)$ \\
CCP+ & $22.1(546 / 2473)$ & $32.8(306 / 934)$ & $41.8(341 / 816)$ & $59.4(740 / 1245)$ \\
\hline \multicolumn{4}{l}{ Data are \% (n/N). }
\end{tabular}

Conclusions: Erosions were common in this cohort of patients, and prevalence of erosions increased with longer disease duration. Patients who were CCP+ had higher rates of prevalent erosions than those who were CCP-with similar disease duration.

Disclosure of Interest: L. Harrold Shareholder of: Corrona LLC, Grant/research support from: Pfizer, AstraZeneca, Consultant for: Roche, Med IQ, K. Price Employee of: Bristol-Myers Squibb, H. Litman Employee of: Corrona LLC, S. Connolly Shareholder of: Bristol-Myers Squibb, Employee of: Bristol-Myers Squibb, E. Alemao Shareholder of: Bristol-Myers Squibb, Employee of: BristolMyers Squibb, S. Rebello Employee of: Corrona LLC, W. Hua Employee of: Corrona LLC, J. Kremer Shareholder of: Corrona LLC, Grant/research support from: AbbVie, Bristol-Myers Squibb, Genentech, Lilly, Novartis, Pfizer, Employee of: Corrona LLC, Speakers bureau: Genentech

DOI: 10.1136/annrheumdis-2017-eular.1657

\section{AB1144 GOOD THERAPEUTIC RESPONSE WITH BIOLOGICS: REMISSION IS REALITY. DATA FROM THE AUSTRIAN BIOREG REGISTRY}

M. Herold ${ }^{1,2}$, G. Eichbauer-Sturm ${ }^{3}$, T. Nothnagl $^{4}$, R. Puchner ${ }^{5}$, B. Rintelen ${ }^{4}$, P. Spellitz ${ }^{6}$, B.F. Leeb ${ }^{4,7}$ on behalf of BioReg Austria. ${ }^{1}$ BioReg Austria, Vienna; ${ }^{2}$ Department of Internal Medicine VI, Innsbruck Medical University, Innsbruck; ${ }^{3}$ Rheumatologist in private practice, Linz; ${ }^{4}$ 2nd Department of Internal Medicine, Lower Austrian State Hospital, Stockerau, ${ }^{5}$ Rheumatologist in private practice, 